\title{
Osteopetrosis complicated by osteomyelitis of the maxilla: A rare case report and review of the literature
}

\section{Osteopetroza powikłana zapaleniem szpiku szczęki - opis rzadkiego przypadku i przegląd piśmiennictwa}

\author{
Moegamat Sallies ${ }^{A-D, F}$, Fadi Titinchi ${ }^{A, B, D, F}$, Jean Morke ${ }^{A, D-F}$ \\ Department of Maxillofacial and Oral Surgery, Faculty of Dentistry and WHO Collaborating Center, University of the Western Cape, Cape Town, South Africa \\ A - research concept and design; B - collection and/or assembly of data; $C$ - data analysis and interpretation; \\ $D$ - writing the article; $E$ - critical revision of the article; $F$ - final approval of the article
}

Address for correspondence

Fadi Titinchi

Email: ftitinchi@uwc.ac.za

Funding sources

None declared

Conflict of interest

None declared

Received on February 16,2020

Reviewed on March 8, 2020

Accepted on April 1, 2020

Published online on September 30, 2020

Cite as

Sallies M, Titinchi F, Morkel J. Osteopetrosis complicated by

osteomyelitis of the maxilla: A rare case report and review

of the literature. Dent Med Probl. 2020;57(3):327-332.

doi:10.17219/dmp/119998

DOI

10.17219/dmp/119998

Copyright

๑ 2020 by Wroclaw Medical University

This is an article distributed under the terms of the

Creative Commons Attribution 3.0 Unported License (CC BY 3.0)

(https://creativecommons.org/licenses/by/3.0/).

\begin{abstract}
Osteopetrosis is a rare hereditary bone disorder that results in an increase in bone density due to gene mutations and osteoclastic dysfunction. This may lead to cranial nerve compression, bone fractures and osteomyelitis. Osteomyelitis of the maxilla is rare even in osteopetrosis patients.

We report on a case of a 25-year-old male who presented with multiple episodes of osteomyelitis of the maxilla following dental extractions. The patient was initially managed with the incision and drainage of an acute infection, and intravenous amoxicillin-clavulanic acid. This was followed by the debridement of necrotic bony margins and packing with bismuth iodoform paraffin paste (BIPP) as well as long-term clindamycin. Once osteomyelitis was clear, the primary closure was achieved with a buccal advancement flap and supported by an acrylic obturator. Challenges in the management are highlighted, including preparing for a surgical intervention a patient with chronic low hemoglobin levels and a lack of healthy bony margins in the maxilla. The literature is also reviewed for similar cases.
\end{abstract}

Key words: osteomyelitis, maxilla, osteopetrosis

Słowa kluczowe: zapalenie szpiku, szczęka, osteopetroza 


\section{Introduction}

Osteopetrosis is a rare hereditary bone disorder that results in an increase in bone density due to gene mutations and osteoclastic dysfunction. The disorder is classically divided into 3 types with variable clinical features. The dominant form of osteopetrosis is typically seen in adults with a late onset whereas the 2 recessive forms of osteopetrosis are typically observed in children with an early onset and a high mortality rate. As bone expansion occurs, marrow spaces become obliterated, which results in fractures, poor wound healing and an increased risk of infections, such as osteomyelitis. Osteomyelitis of the maxilla is relatively rare owing to rich collateral blood supply and thin cortical bone. The diagnosis is established with a thorough history, and physical and radiographic examinations, with the latter being the mainstay. Treatment principles involve managing the identified complications. In the case of osteomyelitis, conservative and preventative care principles play a significant role in the management of patients with osteopetrosis. It is vital that patients with osteopetrosis are made aware of good oral hygiene and dental care practices so as to avoid the need for further treatment. Carious teeth should thus initially be treated with restorations or the endodontic therapy with the aim of preventing tooth extractions and the subsequent surgical complications, such as osteomyelitis. If conservative and preventative measures are compromised, and patients with osteopetrosis develop osteomyelitis, the debridement of necrotic tissue with an adjunctive antibiotic therapy is mandated. ${ }^{1}$

\section{Case report}

A 25-year-old male patient was referred to the Department of Maxillofacial and Oral Surgery at the University of the Western Cape, Tygerberg Hospital in Cape Town, South Africa, with chronic infections and recurrent swelling. The patient reported that the infective process had started 6 months ago, after the extraction of the upper right molar, and had exacerbated 1 day prior to presentation at the clinic.

Past medical history revealed that the patient sustained multiple bone fractures throughout his life, such as forearm and ankle fractures. Upon proceeding with a detailed history, and physical and radiographic examinations, the diagnosis of osteopetrosis with underlying osteomyelitis was confirmed. The patient was not on any chronic medications and had not been on antiresorptive/antiangiogenic agents previously.

Clinically, the patient presented with soft, tender, right facial swelling associated with the right canine space region and the upper lip. Intraorally, the mandible

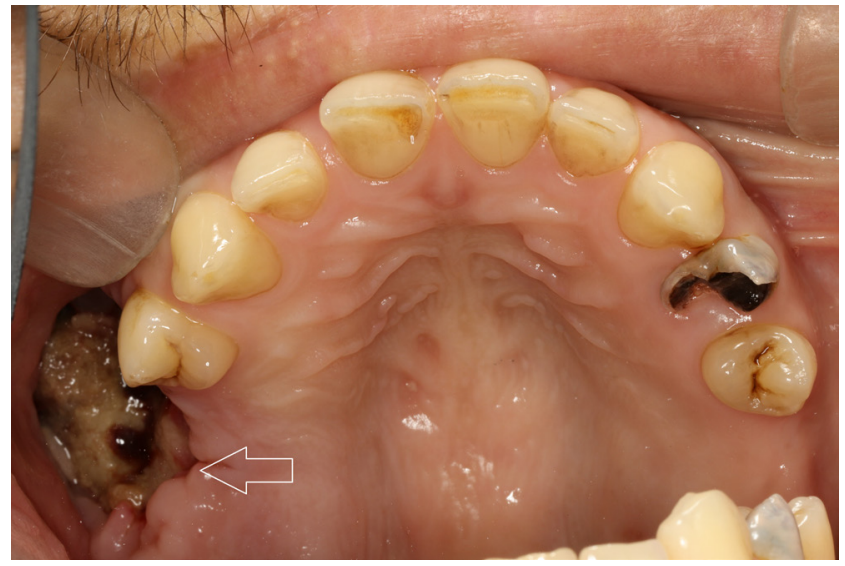

Fig. 1. Intraoral image showing the osteomyelitis of the right maxilla following a dental extraction

appeared edentulous and pus discharge was found in the right maxillary region with a draining fistula associated with the right first molar area (Fig. 1). A radiographic examination demonstrated increased bone opacity, poorly pneumatized paranasal sinuses and multiple unerupted teeth (Fig. 2). Additionally, cone-beam computed tomography (CBCT) further illustrated increased bone opacity with poor differentiation between medullary and cortical bone (Fig. 3).

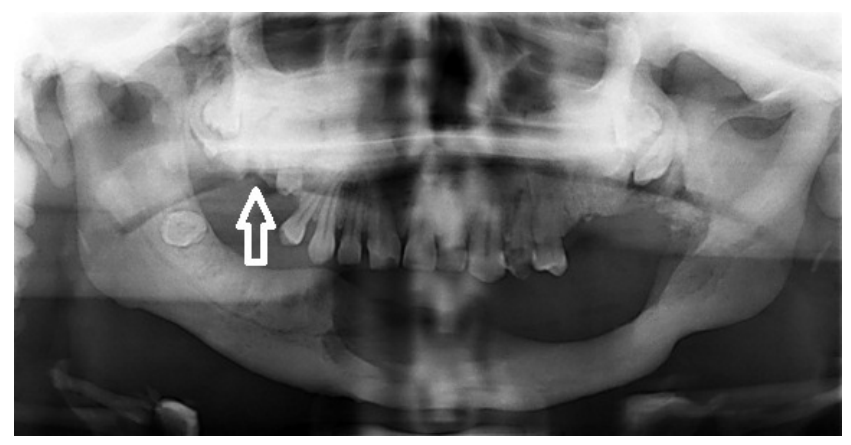

Fig. 2. Pantomograph of the patient showing opacity in the maxilla and multiple unerupted teeth (note the previous marginal resection of the left mandible)

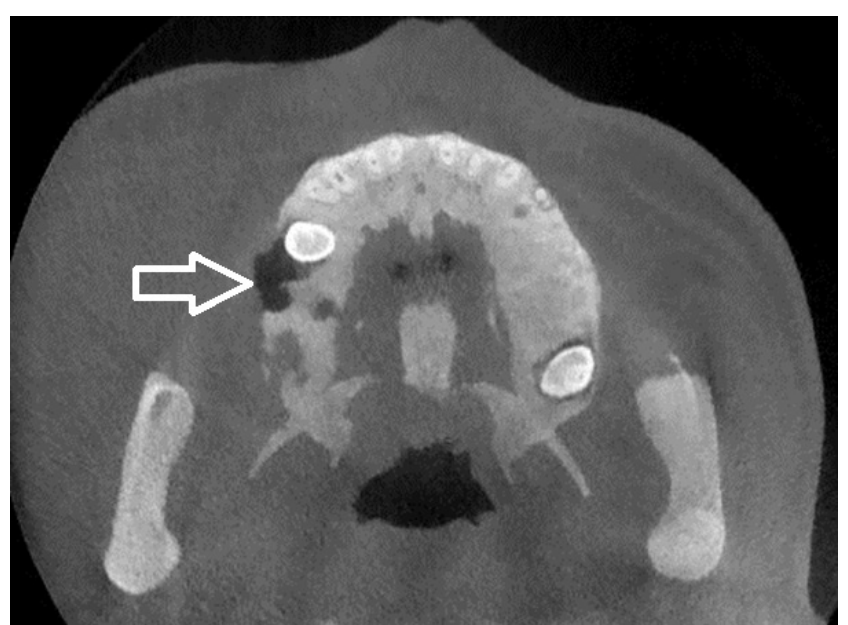

Fig. 3. Axial cone-beam computed tomography (CBCT) scan showing right-sided osteomyelitis in the maxilla 
With regard to the management of the patient at this point, the retained root of a maxillary first molar was surgically removed, incision and drainage were performed, a pus swab was taken, and augmentin IV was administered for 7 days. Following this initial intervention, swelling decreased and the patient reported the alleviation of pain.

Three weeks following discharge, the patient returned, complaining of severe pain and tenderness associated with the same area. An intraoral examination revealed pus discharge from a non-healing maxillary first molar socket with areas of exposed bone. The region was then debrided and packed with bismuth iodoform paraffin paste (BIPP) gauze, the canine space was explored and irrigated, and biopsy was performed. Thereafter, the patient was admitted for 7 days for monitoring and irrigation, with an adjunctive antibiotic therapy in the form of $1.2 \mathrm{~g}$ of augmentin, administered intravenously (i.v.) every $8 \mathrm{~h}$ pending microscopy, culture and sensitivity testing. At day 3 of admission, the patient was switched to $600 \mathrm{mg}$ of clindamycin i.v. every $6 \mathrm{~h}$, as the cultured bacteria were resistant to penicillin. Hematological studies revealed reductions in the red blood cell count $\left(2.78 \times 10^{12} / \mathrm{L}\right)$, hemoglobin $(6.8 \mathrm{~g} / \mathrm{dL})$ and platelet count $\left(146 \times 10^{9} / \mathrm{L}\right)$ with the C-reactive protein level markedly elevated $(83 \mathrm{mg} / \mathrm{L})$. Additionally, the iron level was at the lower limit of the normal range, requiring the prescription of ferric sulfate. The histological examination of the obtained biopsy showed strips of acanthotic, stratified squamous oral mucosa with dense submucosal chronic inflammation (Fig. 4). Fragments of non-vital bone with the surrounding cellular debris, hemorrhage and basophilic bacterial colonization were noted, which was indicative of a sequestrum.

Following that, the patient required 2 additional debridements under general anesthesia with blood transfusions due to chronic low hemoglobin. The patient was also prescribed pentoxifylline and tocopherol orally to aid in bone healing. The wound was then closed, primarily with a buccal advancement flap, and an acrylic obturator was used to support the wound.

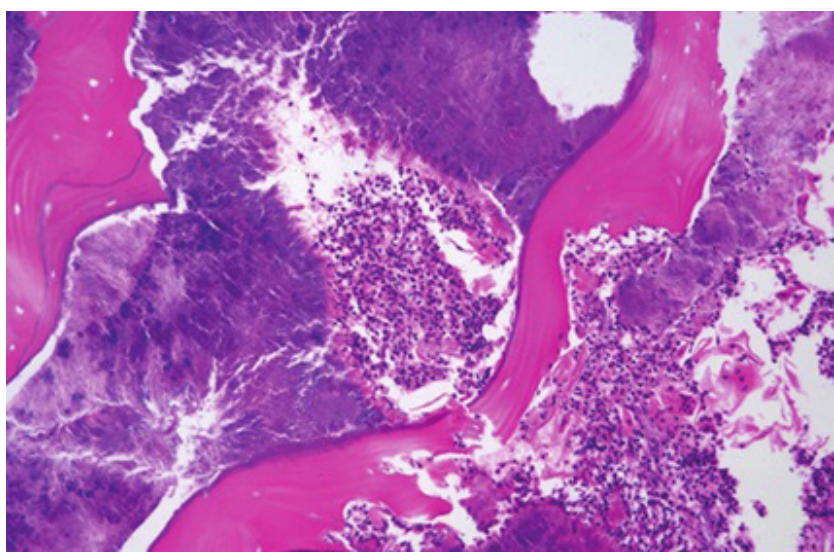

Fig. 4. Hematoxylin and eosin (H\&E)-stained slide showing the signs of suppurative osteomyelitis with inflammatory infiltrate and necrotic bone

\section{Discussion}

Multiple genetic mutations are responsible for the presentation of osteopetrosis. ${ }^{2}$ The mutated genes of significance include CLCN7 and TGIRG1, which results in the functional defects of the enzyme carbonic anhydrase II. ${ }^{2}$ Osteoclasts ultimately cannot form ruffled borders, causing defective bone resorption with the subsequent accumulation of bone, thereby increasing bone density and the fracture risk. ${ }^{2}$

Osteopetrosis is classified into 3 clinical categories, namely benign autosomal dominant, severe malignant autosomal recessive and intermediate mild autosomal recessive. The dominant form of the disorder is more common in adults. In contrast, the rarer autosomal recessive types are typically associated with an early onset and poor prognosis. $^{2}$

Bones in patients with osteopetrosis are poorly vascularized. This adversely affects the healing process and results in a marked increase in infection susceptibility. ${ }^{3}$ As bone becomes denser, its marrow cavities and the pulpal chambers of the teeth become obliterated with the resultant constriction of the neurovascular bundles supplying the jaws and the teeth. ${ }^{3}$ The extension of bone into the cranial nerve foramina and marrow cavities may compromise both hematologic and neurological functions. ${ }^{4}$ Hematological compromises include frequent infections, profound anemia and hepatosplenomegaly, ${ }^{4}$ as in the case of our patient. Neurological compromises may result in nerve palsies, deafness and blindness. ${ }^{4}$ Additionally, dental caries and bone necrosis may also develop as a consequence of bone expansion, which ultimately results in osteomyelitis. ${ }^{5}$ Osteomyelitis is thus a well-known complication associated with osteopetrosis due to its hypovascular nature. ${ }^{1}$ This infection commonly presents in the mandible post-extraction or after the surgical exposure of bone, warranting adequate infection control practices before and after dental surgical procedures. ${ }^{1}$

In the dental setting, patients with osteopetrosis present with complications such as dental caries, premature tooth loss, delayed eruption of teeth, enamel hypoplasia, tooth crown and root malformations, and thickened lamina dura. ${ }^{5}$

The diagnosis of osteopetrosis is based on both clinical and radiographic findings, with the latter being the mainstay. ${ }^{5}$ A radiographic examination reveals diffuse osteosclerosis, involving the spine, the skull, the pelvis, and appendicular bones. Additionally, cortical thickening with the resultant medullary encroachment can be visualised. ${ }^{6}$ Differential diagnoses that are to be considered include metaphyseal dysplasia, pyknodysostosis, diaphyseal sclerosis, osteopathia striata, osteopoikilosis, melorheostosis, Camurati-Engelmann disease, and infantile cortical sclerosis. ${ }^{5}$ 
Table 1. Summary of 24 reported cases of osteomyelitis of the maxilla in patients with osteopetrosis

\begin{tabular}{|c|c|c|c|c|c|}
\hline Study & $\begin{array}{c}\text { Patient's } \\
\text { age }\end{array}$ & $\begin{array}{c}\text { Patient's } \\
\text { gender }\end{array}$ & Clinical signs & Radiographic signs & Management \\
\hline $\begin{array}{l}\text { Celakil et al. } \\
2016^{3}\end{array}$ & 48 & male & purulent discharge from the maxilla & $\begin{array}{l}\text { extensive bone defects } \\
\text { of the maxilla and the } \\
\text { mandible }\end{array}$ & $\begin{array}{l}\text { - dental extractions } \\
\text { - sequestrectomy } \\
\text { - use of a denture as an obturator }\end{array}$ \\
\hline $\begin{array}{l}\text { de Azambuja } \\
\text { Carvalho et al. } \\
2018^{9}\end{array}$ & 40 & male & $\begin{array}{l}\text { pain and swelling of the left buccal, } \\
\text { periorbital and temporal regions, } \\
\text { a fistula in the left maxillary region }\end{array}$ & $\begin{array}{l}\text { CT scan showing } \\
\text { temporoparietal and } \\
\text { maxillary swelling }\end{array}$ & $\begin{array}{l}\text { surgical management: } \\
\text { - incision and drainage } \\
\text { - sequestrectomy } \\
\text { - partial resection of the left maxilla and the } \\
\text { zygomatic bone } \\
\text { - treatment with hyperbaric oxygen } \\
\text { post-operative antibiotics: } \\
\text { - ciprofloxacin for } 6 \text { months } \\
\text { - clindamycin for } 6 \text { months }\end{array}$ \\
\hline $\begin{array}{l}\text { Pavan et al. } \\
2018^{10}\end{array}$ & 13 & male & $\begin{array}{l}\text { diffuse, erythematous, tender swelling } \\
\text { of the right maxillary and zygomatic } \\
\text { regions, a slight mobility of the right } \\
\text { maxillary molars with a discharging } \\
\text { sinus }\end{array}$ & $\begin{array}{l}\text { increased bone density, } \\
\text { the obliteration } \\
\text { of the frontal } \\
\text { and maxillary sinuses }\end{array}$ & $\begin{array}{l}\text { The extractions of necessary teeth and the } \\
\text { sinus tract excision were recommended, } \\
\text { but the patient's parents refused surgical } \\
\text { interventions. } \\
\text { The patient was managed with systemic } \\
\text { antibiotics and blood transfusions due to } \\
\text { the resultant anemia. }\end{array}$ \\
\hline $\begin{array}{l}\text { Kulyapina et al. } \\
2016^{11}\end{array}$ & 66 & male & $\begin{array}{c}\text { oroantral fistula, a non-healing socket } \\
\text { of a third molar with areas of exposed } \\
\text { bone, hearing impairment }\end{array}$ & $\begin{array}{l}\text { area of bone destruction } \\
\text { and sequestrum formation } \\
\text { in the right maxilla }\end{array}$ & $\begin{array}{l}\text { initial management: } \\
\text { - systemic antibiotics for } 1 \text { month } \\
\text { surgical management: } \\
\text { - closure of the oroantral fistula } \\
\text { - sequestrectomy }\end{array}$ \\
\hline $\begin{array}{l}\text { Mikami et al. } \\
2016^{12}\end{array}$ & 54 & male & $\begin{array}{l}\text { pain and swelling of the right facial } \\
\text { region, trismus }\end{array}$ & $\begin{array}{c}\text { radiolucent areas associated } \\
\text { with the maxillary } \\
\text { and mandibular molars }\end{array}$ & $\begin{array}{l}\text { - dental extractions } \\
\text { - sequestrectomy } \\
\text { - cephazolin } \\
\text { - clindamycin }\end{array}$ \\
\hline $\begin{array}{l}\text { de Carvalhosa et al. } \\
2016^{13}\end{array}$ & 6 & female & $\begin{array}{l}\text { avulsion of } 2 \text { maxillary central incisors, } \\
\text { resulting in a non-healing wound, exposed } \\
\text { necrotic bone in the anterior maxilla }\end{array}$ & $\begin{array}{l}\text { intense opacity of the } \\
\text { cortical bone of the maxilla } \\
\text { and the periorbital region }\end{array}$ & $\begin{array}{l}\text { - extractions of unerupted maxillary teeth } \\
\text { - sequestrectomy }\end{array}$ \\
\hline $\begin{array}{l}\text { Infante-Cossio et al. } \\
2014^{14}\end{array}$ & 40 & female & $\begin{array}{l}\text { cutaneous fistula with purulent discharge } \\
\text { from the bilateral submandibular and } \\
\text { right infraorbital regions, exposed } \\
\text { necrotic bone, blindness due to optic } \\
\text { nerve compression }\end{array}$ & $\begin{array}{l}\text { diffuse opacity of the } \\
\text { maxillary and mandibular } \\
\text { bone, } \\
\text { multiple impacted teeth }\end{array}$ & $\begin{array}{l}\text { initial management: } \\
\text { - amoxicillin/clavulanic acid for } 1 \text { month } \\
\text { surgical management: } \\
\text { - local debridement }\end{array}$ \\
\hline $\begin{array}{l}\text { Adachi et al. } \\
2013^{15}\end{array}$ & 44 & female & $\begin{array}{l}\text { fistula with purulent discharge in the } \\
\text { left maxillary buccal region }\end{array}$ & $\begin{array}{l}\text { generalized sclerosis } \\
\text { of the maxilla and the } \\
\text { mandible, the obliteration } \\
\text { of the maxillary sinuses }\end{array}$ & $\begin{array}{l}\text { initial management: } \\
\text { - cefazolin for } 7 \text { days. } \\
\text { surgical management: } \\
\text { - sequestrectomy }\end{array}$ \\
\hline $\begin{array}{l}\text { Arunkumar et al. } \\
2011^{16}\end{array}$ & 54 & male & $\begin{array}{c}\text { chronic discharge, swelling and an ulcer } \\
\text { over the left cheek, a discharging sinus } \\
\text { tract inferior to the left outer canthus, } \\
\text { oroantral fistula }\end{array}$ & $\begin{array}{l}\text { destruction of the alveolar } \\
\text { process in the } 2^{\text {nd }} \text { quadrant } \\
\text { and the left zygomatic arch }\end{array}$ & $\begin{array}{l}\text { - ofloxacin } \\
\text { - extractions of involved teeth } \\
\text { - excision of the fistula } \\
\text { - sequestrectomy }\end{array}$ \\
\hline $\begin{array}{l}\text { Balan et al. } \\
2011^{17}\end{array}$ & 8 & male & $\begin{array}{c}\text { painful left-sided facial swelling with } \\
\text { purulent discharge } \\
\text { from a carious primary molar }\end{array}$ & $\begin{array}{l}\text { increased bone density, } \\
\text { diffuse sclerosis, multiple } \\
\text { unerupted teeth }\end{array}$ & $\begin{array}{l}\text { - systemic antibiotics } \\
\text { - local debridement of the maxilla }\end{array}$ \\
\hline $\begin{array}{l}\text { Khademi et al. } \\
2011^{18}\end{array}$ & 15 & male & $\begin{array}{l}\text { bilateral facial pain and swelling with } \\
\text { infraorbital sinus tract drainage, vision } \\
\text { and hearing problems }\end{array}$ & $\begin{array}{c}\text { obliteration of the maxillary } \\
\text { sinuses, sequestration of the } \\
\text { maxilla and the zygomatic } \\
\text { bone }\end{array}$ & $\begin{array}{l}\text { initial management: } \\
\text { - clindamycin } \\
\text { surgical management: } \\
\text { - curettage } \\
\text { - sequestrectomy } \\
\text { - sinus tract excision }\end{array}$ \\
\hline $\begin{array}{l}\text { Ambika et al. } \\
2010^{19}\end{array}$ & 28 & male & $\begin{array}{l}\text { non-healing extraction socket with } \\
\text { exposed necrotic bone in the right } \\
\text { molar region associated with painful, } \\
\text { extraorally draining facial swelling }\end{array}$ & $\begin{array}{l}\text { increased bone density, erosion } \\
\text { of the buccal cortices of the } \\
\text { right maxilla, the zygomatic } \\
\text { bone, the lateral orbital wall, } \\
\text { and the maxillary sinus }\end{array}$ & $\begin{array}{l}\text { - ciprofloxacin } \\
\text { - local debridement } \\
\text { - sequestrectomy } \\
\text { Partial maxillectomy was planned, but the } \\
\text { patient refused treatment. }\end{array}$ \\
\hline $\begin{array}{l}\text { Oğütcen-Toller et al. } \\
2010^{20}\end{array}$ & 18 & female & $\begin{array}{c}\text { purulent discharge from the infraorbital } \\
\text { and left maxillary molar regions, partial } \\
\text { edentulism with multiple malformed } \\
\text { teeth, blindness }\end{array}$ & $\begin{array}{l}\text { diffuse hyperdensity of the } \\
\text { maxilla and the mandible, } \\
\text { sequestrum formation, } \\
\text { multiple impacted teeth }\end{array}$ & $\begin{array}{l}\text { initial management: } \\
\text { - amoxicillin for } 7 \text { days } \\
\text { surgical management: } \\
\text { - extractions of all partially impacted and } \\
\text { malformed teeth } \\
\text { - sequestrectomy } \\
\text { post-operative antibiotics: } \\
\text { - sultamicillin and ornidazole for } 5 \text { weeks } \\
\text { - treatment was altered to clindamycin for } \\
1 \text { week, sultamicillin and ornidazole for } 3 \text { weeks } \\
\text { followed by cefuroxime axetil for } 4 \text { weeks }\end{array}$ \\
\hline
\end{tabular}


Continued Table 1

\begin{tabular}{|c|c|c|c|c|c|}
\hline Study & $\begin{array}{l}\text { Patient's } \\
\text { age }\end{array}$ & $\begin{array}{r}\text { Patient's } \\
\text { gender }\end{array}$ & Clinical signs & Radiographic signs & Management \\
\hline $\begin{array}{l}\text { Krithika et al. } \\
2009^{21}\end{array}$ & 18 & male & $\begin{array}{l}\text { purulent discharge bilaterally from } \\
\text { buccal mucosa, yellow-white exposed } \\
\text { bone appearing bilaterally in the } \\
\text { maxilla at non-healing molar extraction } \\
\text { sites, vision and hearing impairment }\end{array}$ & $\begin{array}{c}\text { increased bone density with } \\
\text { the diffuse sclerosis of the } \\
\text { maxillary and zygomatic } \\
\text { bones }\end{array}$ & $\begin{array}{l}\text { initial management: } \\
\text { - blood transfusion to address anemia } \\
\text { - augmentin } \\
\text { surgical management: } \\
\text { - corticotomy }\end{array}$ \\
\hline $\begin{array}{l}\text { Krithika et al. } \\
2009^{21}\end{array}$ & 16 & male & $\begin{array}{l}\text { infraorbital, cutaneous pus-draining } \\
\text { sinus following a dental extraction, } \\
\text { generalized enamel hypoplasia, } \\
\text { multiple missing permanent teeth }\end{array}$ & $\begin{array}{l}\text { generalized sclerosis } \\
\text { of bones with an increase } \\
\text { in bone density, the } \\
\text { obliteration of the maxillary } \\
\text { and paranasal sinuses }\end{array}$ & $\begin{array}{l}\text { initial management: } \\
\text { - blood transfusion to address anemia } \\
\text { - levofloxacin for } 1 \text { week } \\
\text { surgical management: } \\
\text { - sequestrectomy }\end{array}$ \\
\hline $\begin{array}{l}\text { Trivellato et al. } \\
2009^{22}\end{array}$ & 25 & male & $\begin{array}{l}\text { recent extraction socket with right } \\
\text { maxillary and mandibular bone } \\
\text { exposure with associated cutaneous } \\
\text { draining fistulas }\end{array}$ & $\begin{array}{l}\text { increased bone density, } \\
\text { multiple edentulous areas }\end{array}$ & $\begin{array}{l}\text { initial management: } \\
\text { - clindamycin } \\
\text { surgical management: } \\
\text { - marginal resection of the right maxilla } \\
\text { and mandible } \\
\text { - partial resection of the mandible after } \\
\text { recurrence }\end{array}$ \\
\hline $\begin{array}{l}\text { Vázquez et al. } \\
2009^{23}\end{array}$ & 23 & female & $\begin{array}{l}\text { infection of the right posterior } \\
\text { maxilla and anterior mandible with } \\
\text { an associated fistula }\end{array}$ & $\begin{array}{l}\text { marked increase in } \\
\text { bone opacity, periapical } \\
\text { radiolucency associated with } \\
\text { the mandibular teeth }\end{array}$ & $\begin{array}{l}\text { - dental extractions } \\
\text { - curettage of sockets } \\
\text { - penicillin IV for } 3 \text { weeks }\end{array}$ \\
\hline $\begin{array}{l}\text { Barry et al. } \\
2007^{24}\end{array}$ & 28 & female & $\begin{array}{c}\text { oroantral fistula, poorly healed } \\
\text { extraction socket with areas of visible } \\
\text { sequestration, mucopurulent discharge } \\
\text { from middle meati }\end{array}$ & $\begin{array}{l}\text { osteosclerosis, moth-eaten } \\
\text { appearance, the bone } \\
\text { destruction of the maxillary } \\
\text { sinus, the hard palate and } \\
\text { the left nasal cavity }\end{array}$ & $\begin{array}{l}\text { conservative management: } \\
\text { - metranidazole } \\
\text { - cefuroxime } \\
\text { - } 0.1 \% \text { betamethasone sodium phosphate } \\
\text { nasal drops }\end{array}$ \\
\hline $\begin{array}{l}\text { Barry et al. } \\
2007^{24}\end{array}$ & 27 & female & $\begin{array}{l}\text { severe halitosis with chronic nasal } \\
\text { discharge, oroantral fistula with } \\
\text { purulent discharge }\end{array}$ & increased bone density & $\begin{array}{l}\text { - amoxicillin/clavulanic acid } \\
\text { - local debridement } \\
\text { - antral wash } \\
\text { - closure of the oroantral fistula with } \\
\text { a buccal advancement flap }\end{array}$ \\
\hline $\begin{array}{l}\text { Junquera et al. } \\
2005^{25}\end{array}$ & 60 & female & $\begin{array}{l}\text { poorly healed extraction sockets } \\
\text { with sequestrum formation } \\
\text { in the } 2^{\text {nd }} \text { quadrant }\end{array}$ & $\begin{array}{l}\text { bone destruction with } \\
\text { visible sequestration }\end{array}$ & $\begin{array}{l}\text { initial management: } \\
\text { - amoxicillin/clavulanic acid for } 1 \text { month } \\
\text { surgical management: } \\
\text { - sequestrectomy }\end{array}$ \\
\hline $\begin{array}{l}\text { Fernandez et al. } \\
2003^{26}\end{array}$ & 9 & female & $\begin{array}{c}\text { painful, erythematous swelling of the } \\
\text { left maxillary region with purulent } \\
\text { discharge from the cutaneous sinus } \\
\text { tract, unerupted maxillary teeth, vision } \\
\text { problems }\end{array}$ & $\begin{array}{l}\text { increased bone density, } \\
\text { radiolucency associated } \\
\text { with first and second molars, } \\
\text { multiple unerupted and } \\
\text { malformed permanent teeth }\end{array}$ & $\begin{array}{l}\text { initial management: } \\
\text { - clindamycin } \\
\text { - blood transfusion to address anemia } \\
\text { surgical management: } \\
\text { - curettage } \\
\text { - local debridement }\end{array}$ \\
\hline $\begin{array}{l}\text { Long et al. } \\
2001^{27}\end{array}$ & 54 & male & $\begin{array}{l}\text { palatal swelling, an oroantral fistula, } \\
\text { multiple draining fistulas of the maxilla }\end{array}$ & $\begin{array}{c}\text { reduced marrow spaces, } \\
\text { areas of necrotic maxillary } \\
\text { bone }\end{array}$ & $\begin{array}{l}\text { - systemic antibiotics } \\
\text { - extractions of remaining maxillary teeth } \\
\text { - local debridement } \\
\text { - sequestrectomy }\end{array}$ \\
\hline $\begin{array}{l}\text { Crockett et al. } \\
1986^{28}\end{array}$ & 24 & female & $\begin{array}{c}\text { diffuse swelling of the left middle and } \\
\text { lower thirds of the face with a draining } \\
\text { sinus tract, soft green-colored exposed } \\
\text { bone in the } 2^{\text {nd }} \text { quadrant }\end{array}$ & $\begin{array}{l}\text { increased bone density, } \\
\text { generalized sclerosis of bone, } \\
\text { bone destruction of the left } \\
\text { maxilla, the antrum and the } \\
\text { zygomatic bone }\end{array}$ & $\begin{array}{l}\text { initial management: } \\
\text { - cefoxitin IV } \\
\text { surgical management: } \\
\text { - removal of polypoid nasal tissue } \\
\text { - sequestrectomy } \\
\text { - left partial maxillectomy } \\
\text { rehabilitation: } \\
\text { - upper denture with an obturator to close } \\
\text { the surgical defect }\end{array}$ \\
\hline $\begin{array}{l}\text { Sofferman et al. } \\
1971^{29}\end{array}$ & 27 & female & $\begin{array}{l}\text { exposed necrotic anterior maxillary } \\
\text { alveolar bone with halitosis and } \\
\text { purulent nasal discharge following the } \\
\text { extractions of the maxillary teeth, total } \\
\text { blindness of the right eye }\end{array}$ & $\begin{array}{l}\text { obliteration of the maxillary } \\
\text { sinuses, sequestration of the } \\
\text { left maxilla }\end{array}$ & $\begin{array}{l}\text { - local debridement } \\
\text { - sequestrectomy } \\
\text { - drains placed from the maxillary sinuses } \\
\text { through nasal antrostomies } \\
\text { - construction of a maxillary prosthesis }\end{array}$ \\
\hline
\end{tabular}

$\mathrm{CT}$ - computed tomography. 
If patients start exhibiting such symptoms as fractures, sepsis, or hematological or neurological abnormalities, medical consultation and management may be necessary. ${ }^{7}$ Management principles aim to modulate and stimulate osteoclastic activity. ${ }^{5}$ Attempts at stimulating osteoclastic activity have been made previously, all with variable success rates, such as utilizing the calcitriol therapy, the regulation of calcium, steroids, and parathyroid hormone. ${ }^{5}$ Palliative treatment involves the debridement of grossly necrotic bone and nerve decompression. ${ }^{5}$ Hemopoietic stem cell transplantation has been proven to be a useful modality to improve the survival rate of patients with the autosomal recessive variants of osteopetrosis. ${ }^{7}$

Treatment modalities that are utilized for osteomyelitis in the jaws secondary to osteopetrosis include incision and drainage, dental extractions, an antibiotic therapy, sequestrectomy, saucerization, decortication, jaw resections, and hyperbaric oxygen. ${ }^{8}$ Obturators are ideally used to close defects; free bone grafts are not recommended due to the compromised blood supply to the graft bed. ${ }^{8}$

No definitive treatment protocol currently exists for osteopetrosis, as shown in Table $1 .^{3,9-29}$

In conclusion, from our experience in the management of this patient and the reviewed literature, patients with osteopetrosis complicated by osteomyelitis of the maxilla should be treated with a long-term antibiotic therapy (amoxicillin/clavulanic acid and/or clindamycin), accompanied with the surgical debridement/sequestrectomy and packing the site with a medicament (BIPP or Whitehead's varnish) to aid in healing and to prevent further infections. Regular long-term follow-up is vital to assess healing and prevent the dissemination of the disease process.

\section{ORCID iDs}

Moegamat Sallies (D) https://orcid.org/0000-0003-1878-8572

Fadi Titinchi (D) https://orcid.org/0000-0003-3182-7038

Jean Morkel (D) https://orcid.org/0000-0001-9338-6712

\section{References}

1. Patil K, Mahima VG, Raina A, Mutneja P. Osteopetrosis: A case report. Int J Med Dent Case Reports. 2016;3:1-3.

2. Jayachandran S, Preethi M. Clinical spectrum of osteopetrosis with secondary osteomyelitis of the mandible: Report of two cases. $J$ Indian Acad Oral Med Radiol. 2018;30(2):165-168.

3. Celakil T, Dogan M, Rohlig BG, Evlioglu G, Keskin H. Oral rehabilitation of an osteopetrosis patient with osteomyelitis. Case Rep Dent. 2016;2016:6930567.

4. Wu CC, Econs MJ, DiMeglio LA, et al. Diagnosis and management of osteopetrosis: Consensus guidelines from the Osteopetrosis Working Group. J Clin Endocrinol Metab. 2017;102(9):3111-3123.

5. García CM, García MAP, García RG, Gil FM. Osteomyelitis of the mandible in a patient with osteopetrosis. Case report and review of the literature. J Maxillofac Oral Surg. 2013;12(1):94-99.

6. Yadav S, Chalise S, Chaudhary S, Shah GS, Gupta MK, Mishra OP. Osteopetrosis in two siblings: Two case reports. BMC Res Notes. 2016;9:55.

7. Povoroznyuk VV, Dedukh N, Bystrytska M, Musiienko AS. Osteopetrosis: Classification, pathomorphology, genetic disorders, clinical manifestations (literature review and clinical case report). Pain Joints Spine. 2019;9(2):135-142.
8. Barry CP, Ryan CD. Osteomyelitis of the maxilla secondary to osteopetrosis: Report of a case. Oral Surg Oral Med Oral Pathol Oral Radiol Endod. 2003;95(1):12-15.

9. de Azambuja Carvalho PH, Moura LB, Gabrielli MFR, Gabrielli MAC, Filho VAP. Maxillary osteomyelitis associated with osteopetrosis: Systematic review. J Craniomaxillofac Surg. 2018;46(11):1905-1910.

10. Pavan BVNKJ, Kejriwal GS, Kumar BL. Maxillary osteomyelitis in Albers-Schönberg disease: A rare presentation. J NTR Univ Health Sci. 2018;7(3):236-239.

11. Kulyapina A, Verdaguer Martin J, Navarro Cuellar C, Navarro Vila C. Long-term follow-up of bimaxillary osteomyelitis associated with autosomal dominant osteopetrosis: A case report. J Maxillofac Oral Surg. 2016;15:121-126.

12. Mikami T, Miake $\mathrm{Y}$, Bologna-Molina R, Takeda Y. Ultrastructural analyses of alveolar bone in a patient with osteomyelitis secondary to osteopetrosis: A review of the literature. J Oral Maxillofac Surg. 2016;74(8):1584-1595.

13. de Carvalhosa AA, Marinho KCT, de Souza Castro PH, Borges ÁH, Volpato LER, Giovani ÉM. Osteomyelitis of the maxilla in a patient with malignant infantile osteopetrosis. Rev Esp Cirug Oral y Maxilofac. 2016;38(2):96-100.

14. Infante-Cossio P, Gonzalez-Perez LM, Martinez-de-Fuentes R, Infante-Cossio M, Castaño-Seiquer A, Jimenez-Castellanos E. Maxillomandibular osteomyelitis associated with osteopetrosis. J Craniofac Surg. 2014;25(1):e79-e82.

15. Adachi M, Iwai T, Watanuki K, Masuda G, Tohnai I. Osteomyelitis of the jaws associated with osteopetrosis: Case report of two sisters. Oral Surg. 2013;6(2):73-76.

16. Arunkumar JS, Naik AS, Prasad KC, Santhosh SG. Role of nasal endoscopy in chronic osteomyelitis of maxilla and zygoma: A case report. Case Rep Med. 2011;2011:802964.

17. Balan A, Girija KL, Ranimol P. Osteomyelitis of maxilla in infantile osteopetrosis: A case report with review of literature. Int J Clin Pediatr Dent. 2011;4(2):125-128.

18. Khademi B, Asefi V, Tarzi M. Osteopetrosis complicated by maxillary osteomyelitis: A case report. Iran J Otorhinolaryngol. 2011;23(64):103-107.

19. Ambika G, Shikha K, Premdeep G, Virendra S. Maxillary osteomyelitis secondary to osteopetrosis - a rare case report. J Clin Diagn Res. 2010;4(5):3261-3265.

20. Oğütcen-Toller M, Tek M, Sener I, Bereket C, Inal S, Ozden B. Intractable bimaxillary osteomyelitis in osteopetrosis: Review of the literature and current therapy. J Oral Maxillofac Surg. 2010;68(1):167-175.

21. Krithika C, Neelakandan RS, Sivapathasundaram B, Koteeswaran D, Rajaram PC, Shetkar GS. Osteopetrosis-associated osteomyelitis of the jaws: A report of 4 cases. Oral Surg Oral Med Oral Pathol Oral Radiol Endod. 2009;108(3):e56-e65.

22. Trivellato AE, Ribeiro MC, Sverzut CE, Bonucci E, Nanci A, de Oliveira PT. Osteopetrosis complicated by osteomyelitis of the maxilla and mandible: Light and electron microscopic findings. Head Neck Pathol. 2009;3(4):320-326.

23. Vázquez E, López-Arcas JM, Navarro I, Pingarrón L, Cebrián JL. Maxillomandibular osteomyelitis in osteopetrosis. Report of a case and review of the literature. Oral Maxillofac Surg. 2009;13(2):105-108.

24. Barry CP, Ryan CD, Stassen LFA. Osteomyelitis of the maxilla secondary to osteopetrosis: A report of 2 cases in sisters. J Oral Maxillofac Surg. 2007;65(1):144-147.

25. Junquera L, Rodríguez-Recio C, Villarreal P, García-Consuegra L. Autosomal dominant osteopetrosis and maxillomandibular osteomyelitis. Am J Otolaryngol. 2005;26(4):275-278.

26. Fernandez JMT, Frias MAN, Hernandez SPD. Infantile osteopetrosis: A case report with osteomyelitis of the maxilla. J Clin Pediatr Dent. 2003;27(1):77-80

27. Long RG, Ziccardi VB, Lejeune C. Osteopetrosis of the maxilla. Oral Surg Oral Med Oral Pathol Oral Radiol Endod. 2001;91(2):139-140.

28. Crockett DM, Stanley RB, Lubka R. Osteomyelitis of the maxilla in a patient with osteopetrosis (Albers-Schönberg disease). Otolaryngol Head Neck Surg. 1986;95(1):117-121.

29. Sofferman RA, Smith RO, English GM. Albers-Schönberg's disease (osteopetrosis). A case with osteomyelitis of the maxilla. Laryngoscope. 1971;81(1):36-46. 